\title{
To study the efficacy of misoprostol compared with methyl ergometrine for prevention of postpartum haemorrhage
}

\author{
Varsha Kotwal \\ Correspondence: Dr Varsha Kotwal, Senior Gynaecologist, Distt. Hospital Doda, Jammu and \\ Kashmir, India; Email - varshakotwal963@gmail.com
}

Distributed under Attribution-NonCommercial - Share Alike 4.0 International (CC BY-NC-SA 4.0)

\begin{abstract}
Objective: Present study was conducted to study the safety and efficacy of misoprostol and methyl ergometrine when used in the prevention of postpartum haemorrhage (PPH). Methodology: In a controlled trial, 100 pregnant women who had a vaginal delivery were assigned into two groups i.e Group 1 and Group 2. Gp1 were treated with oral prostaglandin $E_{1}$ analog misoprostol (400ugm) and Gp2 were treated intravenously with methyl ergometrine $(0.2 \mathrm{mg})$; both after delivery of anterior shoulder of baby. Results: Study revealed that there were no significant differences $(p=0.221)$ when parity, mode of delivery $(p=0.668)$, removal of placenta $(p=0.500)$ and need for oxytocics $(\mathrm{p}=0.134)$ were considered. However, it shows significant differences in length of third stage in both groups. It was further observed that GP1 show short duration of third stage of labour and it also offers advantage over hypertension. Conclusion: Prostaglandins $E_{1}$ analog (Misoprostol) can definitely bring down the incidence of maternal mortality and post partum haemorrhage.
\end{abstract}

Keywords: Misoprostol, methyl ergometrine, postpartum haemorrhage.

Post partum haemorrhage ( $\mathrm{PPH})$ is any bleeding that if left unchecked may results in signs and symptoms of haemodynamic instability. Traditionally, if blood loss is greater than $500 \mathrm{ml}$ in vaginal delivery and greater than $1000 \mathrm{ml}$ in caesarian section is considered as post partum haemorrhage. It is the commonest cause of maternal death worldwide. Post partum haemorrhage is a life threatening obstetric emergency that occurs after caesarean section (CS) or normal vaginal delivery (NVD). It is among three most common etiologies of maternal death worldwide. Its incidence is increasing and it mainly affects $1-5 \%$ of all deliveries ${ }^{1}$. It was also observed that atony is the main cause of PPH and is responsible for about $80 \%$ of PPH. Most of the time, these deaths due to obstetric hemorr- hage are considered to be potentially preventable ${ }^{2,3}$.

Therefore, many uterotonic agents are administered like oxytocin infusion, carboprost tromethamine, methylergometrine, misoprostol etc., among all these drugs, prostaglandins have recently caught much attention. Prostaglandins are active substances with its name originated from the prostate gland and are a group of modified long chain hydroxyl fatty acids. Many prostaglandin analogues have been discovered and the main which are clinically used are $\mathrm{E}_{1}, \mathrm{E}_{2}$ and $\mathrm{F}_{2 \alpha}$. All these have potent oxytocic effect on pregnant uterus. Recently, of all the three, $E_{1}$ analog i.e Misoprostol had received increased attention as a highly effective agent for prevention of $\mathrm{PPH}^{4}$.

Received: $29^{\text {th }}$ April 2019. Accepted: $13^{\text {th }}$ June 2019.

Kotwal V. To study the efficacy of misoprostol compared with methyl ergometrine for prevention of post partum haemorrhage. The New Indian Journal of OBGYN. 2019; 6(1): 49-52. 
Originally, misoprostol was used to prevent peptic ulcers but its potent uterotonic activity has found application in prevention of PPH. It is an effective myometrial stimulant selectively binding to $\mathrm{EP}_{2}$ and $\mathrm{EP}_{1}$ prostanoid receptors ${ }^{5}$. Mostly tablet form of misoprostol has been extensively used for medical termination of first and second trimester of pregnancy, induction of labour and prevention of PPH. These tablets are available under brand name Zytotec, Cytologue (100ugm, 200ugm). However, it is used with caution in case of cardiovascular diseases, renal diseases, peptic ulcers, jaundice, diabetes, seizure disorder and prior uterine surgery.

Another major drug which was reported earlier was ergot alkaloid which is used for stimulation of uterus. It was obtained from fungus Claviceptus purpurea. It acts directly on smooth muscle cell receptors. Uterus is very sensitive to ergot stimulation and power contractions may persist for hours. Moreover, they are detoxified in liver and excreted in urine. Two important alkaloids are: Ergonovine maleate (ergotrate) and Methylergonovine maleate (Methergine). Both starts to act 40 seconds when used intravenously and 7 minutes when used intramuscularly. Its possible side effects are nausea, vomiting and cardiovascular collapse.

The aim of the present study was therefore to compare the efficacy and safety of using oral misoprostol and intravenous methyl ergometrine in the prevention of post partum haemorrhage.

Table 1: Various parameters of group 1 and group 2

\begin{tabular}{|c|c|c|c|c|}
\hline \multicolumn{2}{|l|}{ Categories } & $\begin{array}{l}\text { Prostaglandin E1 } \\
\mathbf{N}=50\end{array}$ & $\begin{array}{l}\text { Methylergometrine } \\
\mathrm{N}=\mathbf{5 0}\end{array}$ & P value \\
\hline \multicolumn{2}{|l|}{ Age in years $($ Mean $\pm \mathrm{SD})$} & $26.96 \pm 3.87$ & $26.06 \pm 3.06$ & 0.123 \\
\hline \multirow{2}{*}{ Parity in number $(\%)$} & Primi & $33(66 \%)$ & $27(54 \%)$ & 0.221 \\
\hline & Multi & $17(34 \%)$ & $23(46 \%)$ & \\
\hline \multirow[t]{2}{*}{ Modes of delivery in number } & Normal delivery & 40 & 38 & 0.668 \\
\hline & Instrumental delivery & 10 & 12 & \\
\hline \multirow{2}{*}{$\begin{array}{l}\text { Comparison of blood loss in } \\
\text { postpartum period in } \mathrm{ml}\end{array}$} & Mean & $226.98 \pm 47.26$ & $236 \pm 31.77$ & 0.79 \\
\hline & Range & $160-400$ & $190-500$ & \\
\hline \multicolumn{2}{|c|}{ Manual removal of placenta in no $(\%)$} & $3(6 \%)$ & $4(8 \%)$ & 0.500 \\
\hline \multicolumn{2}{|c|}{ Need further oxytocics no (\%) } & $6(12 \%)$ & $2(4 \%)$ & 0.134 \\
\hline \multicolumn{2}{|l|}{$\begin{array}{l}\text { Length of third stage of labour } \\
(\text { Mean } \pm \text { SD })\end{array}$} & $\begin{array}{l}5 \text { minutes } 16 \text { seconds } \\
\pm 2 \text { minutes } 31 \mathrm{sec}\end{array}$ & $\begin{array}{l}8 \text { minutes } 5 \text { seconds } \pm \\
3 \text { minutes } 30 \text { seconds }\end{array}$ & $<0.001$ \\
\hline \multirow{2}{*}{$\begin{array}{l}\text { Haemoglobin in gm } \\
\quad(\text { Mean } \pm \text { SD })\end{array}$} & Pre delivery & $10.24 \pm 0.70$ & $10.26 \pm 0.50$ & 0.875 \\
\hline & Post delivery & $9.31 \pm 0.62$ & $9.32 \pm 0.48$ & 0.485 \\
\hline \multicolumn{2}{|l|}{ Methods } & \multicolumn{3}{|c|}{ was $26.96 \pm 3.87$ years. Study revealed that there were no } \\
\hline \multicolumn{2}{|c|}{$\begin{array}{l}\text { Present study was conducted at L.D Hospital of GMC, } \\
\text { Srinagar. Prior to the study detailed history with regard to }\end{array}$} & significant differences & $(\mathrm{p}=0.221)$ when parity & mode of \\
\hline
\end{tabular}

name, age, parity, residence, period of gestation and menstrual history were asked. Detailed physical examination was done. All patients were underwent obstetric examination. Complete haemogram was also done which include: Hb level, Blood grouping and typing, Total leucocyte count, Peripheral blood film.

Case under study consists of 100 women delivering vaginally. Group 1 having 50 women who were treated with oral prostaglandin $\mathrm{E}_{1}$ analog Misprostol (400ugm) and 50 patients in Group 2 who were treated with methylergometrine $(0.2 \mathrm{mg})$; both after delivering anterior shoulder of baby. Patient were kept in lithotomy position after delivery of baby and placenta and the blood loss was measured by collecting the blood in tray (dish) placed below the perineum. This was done for the patients who had no episiotomy. But the patients who had undergone episiotomy, guaze packing were used which were kept in vagina after delivery of baby and placenta. These were weighed before and after use and blood loss was calculated accordingly. After that during first 24 hours, sanitary pads were used which were also weighed before and after use and blood loss was estimated. Statistical calculations were done by calculating $\mathrm{P}$ value.

\section{Results}

Hundred women were included in the study i.e 50 in Group 1 (oral prostaglandin $\mathrm{E}_{1}$ analog misoprostol 400ugm) and 50 in Group 2 (intravenously with methyl ergometrine $0.2 \mathrm{mg}$ ). The mean age of study participants 
The New Indian Journal of OBGYN. 2019 (July-December); 6(1)

Table 2: Showing the side effects of both the drugs

\begin{tabular}{|c|c|c|}
\hline Categories & Prostaglandin $E_{1}(n=50)$ & Methylergometrine $(\mathrm{n}=\mathbf{5 0})$ \\
\hline Vomiting & $6(12 \%)$ & $8(16 \%)$ \\
\hline Loose motion & $15(30 \%)$ & $\ldots$ \\
\hline Headache & $01(2 \%)$ & $17(34 \%)$ \\
\hline Tachycardia (120/min.) & ...... & $15(30 \%)$ \\
\hline Increase in mean blood pressure by more than $10 \mathrm{~mm} \mathrm{Hg}$ & $\ldots \ldots$ & $20(40 \%)$ \\
\hline Abdominal pain & $12(24 \%)$ & $6(12 \%)$ \\
\hline
\end{tabular}

$(\mathrm{p}=0.79)$, removal of placenta $(\mathrm{p}=0.500)$ and need for oxytocics $(p=0.134)$ were considered. However, it shows significant differences in length of third stage of labour in both groups $(<0.001)$ (Table 1$)$. It was further observed that GP1 show more number of loose motion and abdominal pain. Headache, tachycardia and increased blood pressure were observed in methylergometrine group (Table 2).

\section{Discussion}

During the present study, we compared the safety and efficacy of misoprostol and methyl ergometrine in the prevention of postpartum haemorrhage. Our analysis showed that there were no statistically significant difference in the baseline characteristics in the two groups (Tables 1). However significant difference was found in length of third stage in both groups. On an average, placenta was expelled 3 minutes earlier in misoprostol group. There was insignificant difference in haemoglobin levels 24 hours after delivery $(p=0.485)$. Haemoglobin levels post delivery was comparable in the two groups.

Thus present study revealed that prostaglandin $\mathrm{E}_{1}$ analog (Misoprostol) was more effective in reducing the duration of third stage of labour as compared to methylergometrine. There was a highly significant difference $(p<0.001)$ in the duration of third stage of labour in patients receiving prostaglandin $E_{1}$ in comparison to methyl ergometrine. Similarly Pat Brien ${ }^{6}$ also suggested that median length of third stage was 5 minutes with prostaglandin $\mathrm{E}_{1}$ and 8.4 minutes with methyl ergometrine with $\mathrm{p}$ value $<0.001$. Similar results have been reported by G. Justus Hofineyer ${ }^{7}$. They observed that duration of third stage was shortened to 6.1 minutes following methyl ergometrine and 4.5 minutes following misoprostol.

During the present study, 100 patients of age ranged between 18-44 years and parity between 1 and 6 were considered. Statistically there was no significant difference $(p=0.123)$ between the two groups. Similar results have been revealed by Fredric Amant et al ${ }^{8}$ who study two hundred patients and parity between 1 and 6 and Hazem et al ${ }^{4}$ who study two hundred thirty seven patients and parity between 1 and 6 .

Present study also revealed that out of 100 patients, 3 patients in misoprostol group and one patient in methyl ergometrine group needed manual removal of placenta. Statistically the differences between the two groups were insignificant $(\mathrm{p}=0.50)$. One patient in misoprostol group and one patient in methyl ergometrine group needed blood transfusion. Similar results have been reported by Frederic Amant et al ${ }^{8}$ who study two hundred patients. Out of them, 3 in misoprostol group and 4 patients in methyl ergometrine group needed manual removal of placenta and one patient in each group needed blood transfusion.

As far as mode of delivery is concerned, present study revealed that among 100 patients, 78 patients had normal delivery while 22 patients had instrumental delivery (vacuum 18 forceps 4). There was no significant differences between the two groups $(p=0.629)$. Similar results have been observed by Amant et al. ${ }^{8}$

During the present study, it was observed that six patients in misoprostol group and 2 patients in methyl ergometrine group needed further oxytocics. Similar trend had been shown by Bernard Spitz et al ${ }^{9}$ who study 200 patients out of which 4 patients in methyl ergometrine group and 12 patients in misoprostol group needed further oxytocics.

As far as the efficiency of both the drugs for preventing blood loss is concerned, it was found that both the drugs are comparable in preventing the blood loss with no significant differences. Average blood loss measured was $160-400 \mathrm{ml}$; with the use of prostaglandin and 190-500 $\mathrm{ml}$ with the use of methyl ergometrine. Similar reports have been found by Lam et al ${ }^{10}$ where 
The New Indian Journal of OBGYN. 2019 (July-December); 6(1)

median blood loss was $280 \mathrm{ml}$ versus $226 \mathrm{ml}, \mathrm{p}=0.45$. El Rafaey et al ${ }^{11}$ found that $12 \%$ patients in misoprostol group and $11 \%$ patients in methylergometrine group had postpartum haemorrhage. Blood loss was $1000 \mathrm{ml}$.

Present study revealed that predelivery haemoglobin in misoprostol group was $10.24 \pm 0.70 \mathrm{gm} \%$ and in methyl ergometrine group it was $10.26 \pm 0.58 \mathrm{gm} \%(\mathrm{p}=0.875)$. Post delivery $\mathrm{Hb}$ was $9.31 \pm 0.62 \mathrm{gm} \%$ in misoprostol group and $9.23 \pm 0.48 \mathrm{gm} \%$ in methyl ergometrine group. Comparable results have been found by Frederic Amant et al $^{8}$.

Possible side effects were also observed eg. vomiting in $12 \%$ patients, loose motions in $30 \%$ patients, headache in $2 \%$ patients and abdominal pain in $24 \%$ patients in the group 1. While in group 2, vomiting occurs in $16 \%$ patients, headache in $34 \%$ patients, tachycardia in $30 \%$ patients and increase in BP by $10 \mathrm{~mm}$ of $\mathrm{Hg}$ in $40 \%$ patients.

\section{Conclusion}

Thus present study clearly showed that oral administration of misoprostol is highly recommended for the prevention of post partum haemorrhage as it shortens the duration of third stage of labour as compared to methyl ergometrine and is also comparable in preventing blood loss. It also offers an advantage in case of hypertension over methyl ergometrine.

\section{Conflict of interest: None. Disclaimer: Nil.}

\section{References}

1.Bale JR, Stoll BJ, Lucas AO, editors. Institute of Medicine (US) Committee on Improving Birth Outcomes. Washington (DC): National Academies Press (US); 2003.

2.Knight M, Kenyon S, Brocklehurst P, Neilson J, Shakespeare J, Kurinczuk. Saving Lives, Improving Mothers' Care - Lessons learned to inform future maternity care from the UK and Ireland Confidential Enquiries into Maternal Deaths and Morbidity 2009-12. Oxford: University of Oxford; 2014.
3.Enquète Nationale Confidentielle sur les Morts

Maternelles, France 2007-2009. Rapport du Comité National d'experts sur la Mortalité Maternelle (CNEMM); 2013.

4.El-Refaey H, O’Brien P, Morafa W, Walder J, Rodeck C. Use of oral misoprostol in the prevention of postpartum haemorrhage. British Journal of Obstetrics \& Gynaecol. 1997; 104(3): 336-9.

5.Senior J, Marshall K, Sangha R, Clayton JK. In vitro characterization of prostanoid receptors on human myometrium at term pregnancy. Br J Pharmacol.1993; 108(2): 501-6.

6.El-Rafaey H, O’ Brien P, Morafa W, Walder J, Rodeck C. Misoprostol for third of stage of labor. Lancet. 1996: 347: 1257.

7.Hofmeyr GJ, Gülmezoglu AM, Novikova N, Linder V, Ferreira S, Piaggio G. Misoprostl to prevent and treat postpartum haemorrhage: a systemic review and metaanalysis of maternal deaths and dose-related effects. Bull World Health Organ. 2009 Sep; 87(9): 666-77.

8.Amant F, Spitz B, Timmerman D, Corremans A, Van Assche FA. Misoprostol compared with methylergometrine for prevention of post partum haemorrhage. British journal of obstetrics and Gynaecology.1999; 106(10): 1066-70.

9.Bechard de spirlet M. Use of misoprostol in gynaecology and obstetrics. Gynaecol Obstet Fertil. 2002 April; 30 (4): 317-24.

10.Lam H, Tang OS, Lee CP, Ho PC. A pilot-randomized comparison of sublingual misoprostol with syntometrine on the blood loss in third stage of labor. Acta Obstet Gynecol Scand. 2004; 83(7): 647-50.

11.El-Refaey H, Nooh R, O'Brien P, Abdalla M, Geary M, Walder J, Rodeck C. The misoprostol third stage of laour study; a randomzed controlled trial between orally administered misoprostol and standard management. B JOG. 2000 Sep; 107 (9): 1104-10.

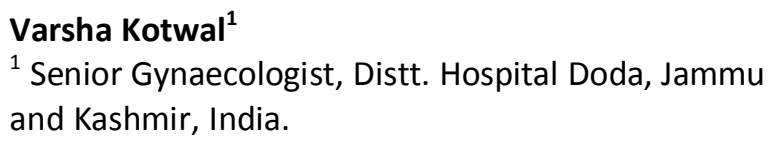

